\title{
ANALISIS HISTOLOGIS GINJAL, HATI DAN JANTUNG IKAN LELE AFRIKA Clarias gariepinus YANG MENGALAMI ANOMALI PADA SIRIP PEKTORAL
}

\author{
Hidayatul Laily ${ }^{1}$, Farikhah ${ }^{2}$, Ummul Firmani $^{2}$ \\ ${ }^{1}$ Mahasiswa Prodi Akuakultur Fakultas Pertanian Universitas Muhammadiyah Gresik \\ ${ }^{2}$ Dosen Prodi Akuakultur Fakultas Pertanian Universitas Muhammadyah Gresik \\ Diyahnovianti28@gmail.com; +6289677483385
}

\begin{abstract}
The purpose of this study was to describe the histology of kidney, liver and heart organs in African catfish Clarias gariepinus not pectoral fin which originated from maintenance in aquaculture ponds. The study was conducted in June 2018 at the Reproductive Laboratory of Fisheries Cultivation Study Program, Department of Water Resources Management, Faculty of Fisheries and Marine Sciences, Brawijaya University, Malang. This research method is descriptive of the object under study that is abnormal fish and the sample specified is 3 individuals. There are 3 target organs, namely kidney, liver and heart. As a comparison, a normal fish sample is used, which is a complete pectoral fin fish. Each organ is examined by the parts that most play a role in the function of the organ. The results of the study showed that abnormal African catfish glomelurus underwent changes that merged with the bowman capsule, whereas in the liver it was found that the hepatocyte nucleus was shrinking and fading. In the heart organ the pericardium layer appears thinner.
\end{abstract}

Keywords: anomalies, histology, kidneys, liver, heart, pectoral fins

\begin{abstract}
ABSTRAK
Tujuan penelitian ini adalah untuk mendeskripsikan histologi organ ginjal, hati dan jantung pada ikan lele Afrika Clarias gariepinus tidak bersirip pektoral yang berasal dari pemeliharaan di kolam budi daya. Penelitian dilakukan pada bulan Juni 2018 di Laboratorium Reproduksi Program Studi Budidaya Perikanan Jurusan Manajemen Sumber Daya Perairan Fakultas Perikanan dan Ilmu Kelautan Universitas Brawijaya Malang. Metode penelitian ini adalah deskriptif terhadap objek yang diteliti yaitu ikan abnormal dan sampel yang ditentukan sebanyak 3 individu. Organ target ada 3 yaitu ginjal, hati dan jantung. Sebagai pembanding, digunakan sampel ikan normal yaitu ikan yang bersirip pektoral lengkap. Setiap organ diteliti bagian-bagian yang paling berperanan dalam fungsi organ tersebut. Hasil penelitian menujukkan pada ikan lele Afrika abnormal glomelurus mengalami perubahan yang menyatu dengan kapsul bowman, sedangkan pada hati ditemukan inti sel hepatosit yang menyusut dan memudar. Pada organ jantung lapisan pericardium nampak lebih tipis.
\end{abstract}

Kata Kunci: anomali,histologi, ginjal, hati, jantung, sirip perktoral 


\section{PENDAHULUAN}

Anomali sirip merupakan salah satu bentuk penyimpangan morfologis yang sering terjadi pada ikan yang dibudidayakan. Frekuensi sirip yang terkena dan tingkat keparahan anomali sangat bervariasi menurut spesiesnya, cara pemeliharaan, dan wadah budidaya. Kondisi erosi sirip atau sirip yang di gigit karena efek kepadatan tidak dipertimbangkan sebagai penyimpangan anomali. Secara umum, sirip anomali diamati yang paling parah kurang lengkapnya sirip, posisi sirip yang tidak tepat, tetapi penyimpangan tersebut langka atau terbatas pada lahan budidaya atau tempat percobaan untuk spesies baru (Boglione et al, 2013). Beberapa laporan menyebutkan bahwa faktor yang mengakibatkan terjadinya penyimpangan anomali yaitu faktor genetik dan lingkungan. Faktor genetik yang mendasari penyimpangan anomali muncul selama program seleksi genetik yang ditujukan untuk meningkatkan pertumbuhan yang cepat.

Pada kasus di Eropa terdapat budidaya ikan salmon yang banyak ditemukan pula penyimpangan asimetri yang merugikan sekitar $€ 50.000 .000$ setiap tahun. Apabila anomali ikan dapat dikurangi 50\% maka dapat menghemat kerugian $€ 25.000 .000$ per tahun, sehingga dapat meningkatkan produktifitas, profitabilitas, dan meningkatkan citra akuakultur (Hough, 2009). (Nurhidayat et al, 2000) memaparkan benih strainstrain ikan lele Afrika yang dibudidayakan juga mengalami deformitas berkisar $6,00 \%$ $42,00 \%$ pada sentra budidaya di Indonesia.

Data tersebut menunjukkan bahwa kejadian anomali morfologi ikan di Indonesia cukup tinggi khususnya untuk komoditas ikan lele Afrika. Tingginya frekuensi abnormalitas ikan budidaya adalah problem yang perlu diatasi dan dicariikan masalah langkah pencerahnnya.Upaya mengatasi problem tersebut, diawali dengan observasi yang mendalam tentang penyimpangan yang terjadi. Mengingat pentingya organ sirip berpasangan bagi ikan lele Afrika sebagai pendukung daya hidupnya, dan adanya anomali yang bersifat merugikan. Perlu dilakukannya penyelidikan histology organ berpasangan yang dialami pada ikan lele hasil pembudidayaan.

\section{METODE PENELITIAN}

Penelitian dilakukan di Laboratorium Reproduksi Ikan Program Studi Budidaya Perairan Jurusan Manajemen Sumber Daya Perairan Fakultas Perikanan dan Ilmu Kelautan Universitas Brawijaya pada bulan Juni 2018. Metode Penelitian adalah deskriptif terhadap dua populasi anakan atau keturunan (F1) ikan lele Afrika Clarias gariepinus, yaitu F1 dari induk ikan tak bersirip pektoral dan F1 dari induk ikan normal (kontrol). Ikan tak bersirip pektoral yang digunakan sebagai induk dalam penelitian ini berasal dari pengepul ikan di Pasar Induk Ikan Lamongan Jawa Timur, sedangkan ikan normal yang digunakan sebagai induk, berasal dari Laboratorium Reproduksi Ikan FPIK Universitas Brawijaya.

Metode penelitian ini adalah deskriptif terhadap objek yang diteliti yaitu ikan abnormal dan sampel yang ditentukan sebanyak 3 individu. Organ target ada 3 yaitu ginjal, hati dan jantung. Sebagai pembanding, digunakan sampel ikan normal yaitu ikan yang bersirip pektoral lengkap. Setiap organ diteliti bagian-bagian yang paling berperanan dalam fungsi organ tersebut.

\section{Isolasi Jaringan}

Sampel ikan dianestesi dan di bedah pada bagian perut, kemudian organ target di potong dan diambil secara hati-hati dengan menggunakkan pinset kemudian organ target dimasukkan dnalam botol sampel. Selanjutnya dituangkan formalin $10 \%$ sebanyak volume $10 \mathrm{x}$ organ dimasukkan, kemudian botol sampel ditutup rapat dan diberi label. 


\section{Pembuatan Preparat dengan Pewarnaan Hemaxtocylin Eosin (HE)}

Jaringan dipotong sekitar $1 \mathrm{~cm} \times 1 \mathrm{~cm}$ kemudian jaringan direndam dalam formalin $10 \%$ selama 24 jam. Selanjutnya jaringan tersebut dimasukkan dalam larutan alkohol dengan kosentrasi rendah ke kosentrasi tinggi kemudian direndam dalam cairan xylol yang diletakkan dalam wadah kaca. Selanjutnya jaringan dipadatkan menggunakkan paraffin kemudian dipotong dengan menggunakkan mikrotom. Proses selanjutnya jaringan diletakkan pada wadah cetakan kayu selama 12 jam kemudian jaringan dipotong mengunakkan microtome knife dan microtome blade. Selanjutnya jaringan diparanifisasi xylol 2 × 2 menit kemudian di rehidrasi dengan larutan alkohol dan dibilas air kran selama 3 menit kemudian direndam dalam larutan Hematoxylin Mayer selama 5-10 menit. Selanjutnya dilakukan counterstaining dengan eosin working solution selama 3 menit kemudian di dehidrasi dalam larutan alkohol dan di rendam kembali dalam xylol 2 × 2 menit kemudian diberikan 1 tetes Canada balsam diatas deck glass dan ditutupkan ke atas kaca objek. Tahap akhir dengan memberikan label nama pada preparat jaringan yang telah selesai dibuat.

\section{Pengamatan Preparat}

Pengamatan jaringan diamati dengan mikroskop Olympus BX21 scan dotslide olyvia dengan perbesaran 400x untuk mengamati setiap bagian-bagian organ yang ditargetkan.

\section{HASIL DAN PEMBAHASAN}

\section{Jaringan Ginjal Ikan Lele Afrika Clarias gariepinus}

Perbedaan struktur ginjal ikan lele Afrika bersirip lengkap dengan ikan lele Afrika tanpa sirip pectoral dapat dilihat pada Gambar 1.

\begin{tabular}{l|l}
\hline $\begin{array}{l}\text { Struktur Ginjal Ikan Lele Afrika Sirip } \\
\text { Pektoral Normal }\end{array}$ & $\begin{array}{l}\text { Struktur Ginjal Ikan Lele Afrika Tanpa } \\
\text { Sirip Pektoral }\end{array}$ \\
\hline
\end{tabular}

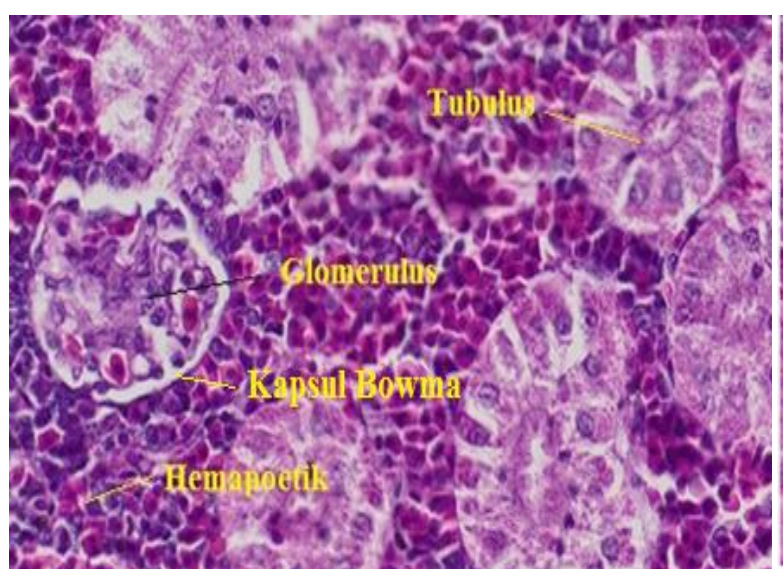

Ulangan 1

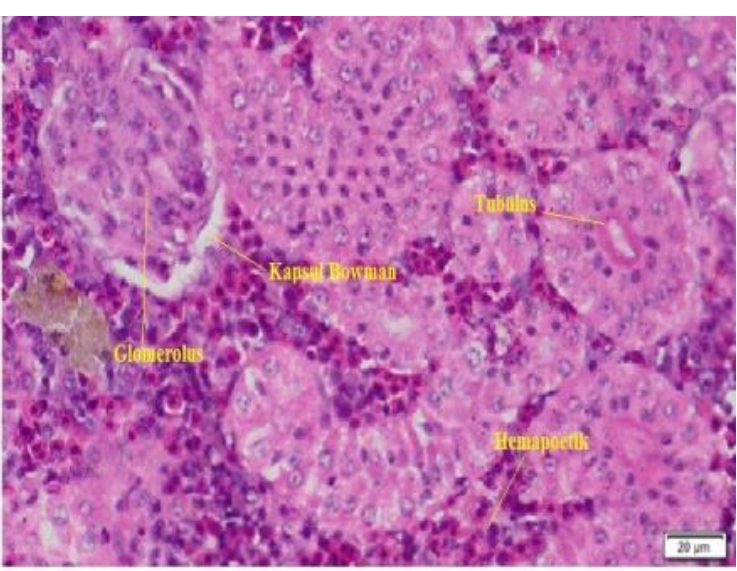

Ulangan 1 


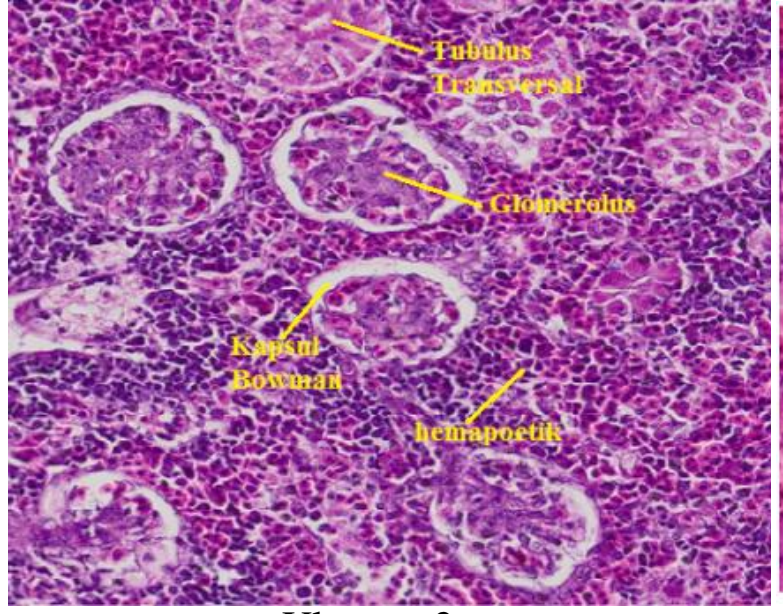

Ulangan 2

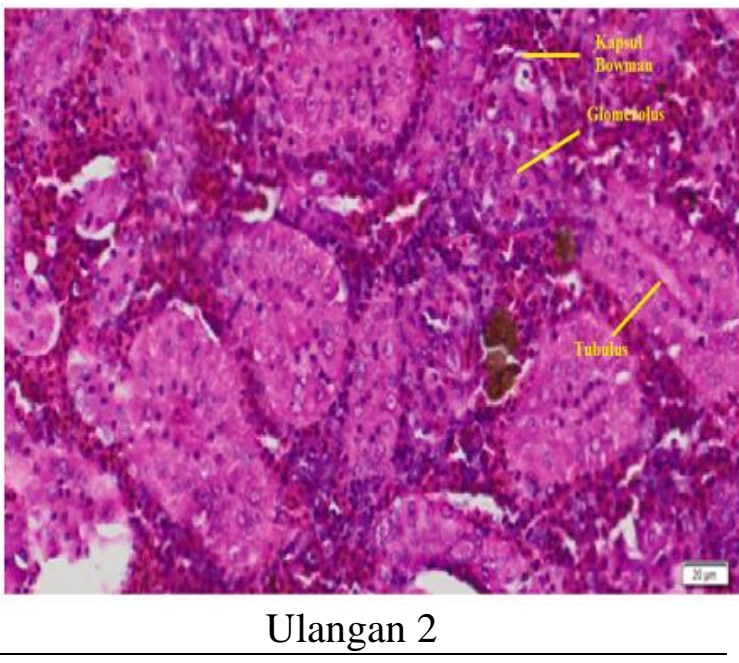

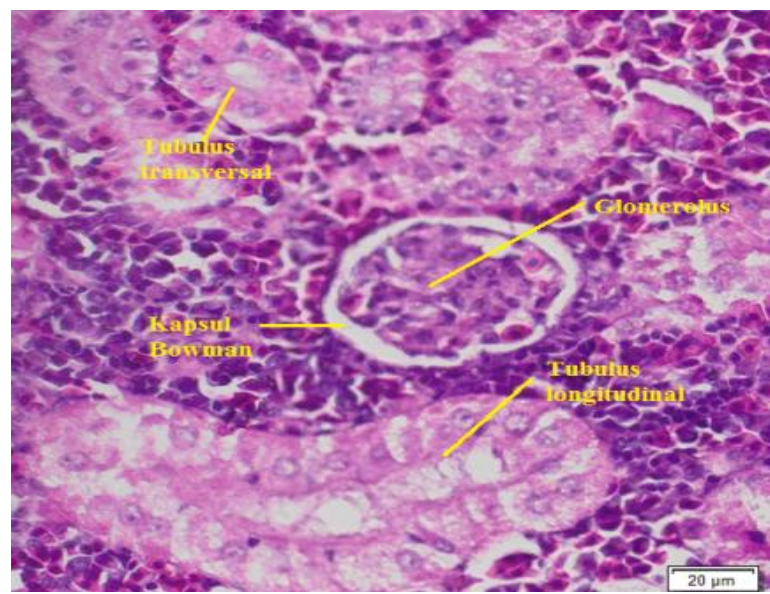

Ulangan 3

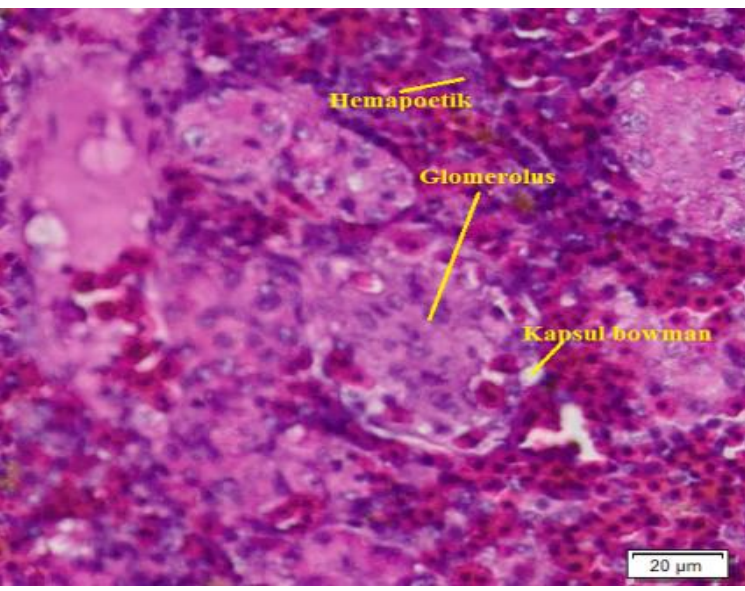

Ulangan 3

Gambar 1.Hasil dari struktur ginjal ikan lele normal dengan struktur ginjal ikan lele abnormal (hilangnya kedua sirip pektoral) pada ulangan 1, 2 dan 3 dengan perbesaran yang sama 400x ditemukan perbedaan pada beberapa jaringan. Pada jaringan glomerolus ikan lele normal ulangan 1, 2 dan 3 mempunyai bentuk yang menyusut dan menjauh dari kapsul bowman. Sedangkan pada ikan abnormal ulangan 1, 2 dan 3 kapsul bowman, glomerolus dan tubulus tampak menyatu.

Ginjal ikan merupakan organ yang terdiri dari cmpuran hemapoetik, retikuloendotelial, endokrin dan bagian ekskretoris. Ginjal pada ikan terletak di luar ruang peritorium, menempel di bawah tulang punggung, memenajang dari dekat anus kea rah depan hingga ujung rongga perut. Warna ginjal dalam keadaan normal umumnya merah kehitaman. Secara umum, struktur histologi ginjal terdiri dari unsur utama yaitu glomerulus, tubulus dan pembuluh darah (Mc Gavin dan Zachary, 2007). Struktur jaringan ginjal ini sesuai dengan Takashima dan Hibiya (1995) yang menyatakan bahwa pada ginjal ikan normal juga terlihat adanya kapsula Bowman yang mengelilingi glomerulus.

Pada Ginjal ikan gabus memiliki ukuran glomerulus yang relatif besar yang mengisi kapsula Bowman, hal ini sesuai dengan penelitian Bruno et al (2010) yang menyatakan bahwa tipe nefron dari ikan salmon yang hidup di air tawar mempunyai karakteristik glomerulus yang relatif besar. Glomerulus dalam keadaan normal secara keseluruhan tertutup oleh kapsula bowman yang berbentuk mangkok, kapiler glomerulus dilapisi oleh sel-sel endotel, berlubang pori-pori dengan diameter kurang lebih $100 \mathrm{~nm}$ dan terletak pada membran basalis. Di bagian luar membran basalis adalah epitel viseral (podosit). 
Pada ikan sakit/ kondisi yang tidak menguntungkan, sel-sel pada kapsula Bowmandan glomerulus ini akan mengalami degenerasi/ kerusakan. Kerusakan dapat menyebabkan berbagai dampak baik secara morfologi maupun fungsional. Secara morfologis kerusakan glomerulus ditandai dengan terjadinya nekrosis dan ploriferasi dari sel membran serta infiltrasi leukosit. Rusaknya glomerulus secara fungsional ditandai dengan berkurangnya perfusi aliran darah, lolosnya protein dan makromolekul lain dalam jumlah yang besar pada filtrat glomerulus. Kerusakan pada glomerulus juga dapat berupa atrofi dan fibrosis sehingga menyebabkan atrofi sekunder pada tubulus renalis.

\section{Jaringan Hati Ikan Lele Afrika Clarias gariepinus}

Perbedaan struktur hati ikan lele Afrika bersirip lengkap dengan ikan lele Afrika tanpa sirip pectoral dapat dilihat pada Gambar 2.

\begin{tabular}{l|l}
\hline Struktur Hati Ikan Lele Afrika Sirip & $\begin{array}{l}\text { Struktur Hati Ikan Lele Afrika Tanpa } \\
\text { Pektoral Normal }\end{array}$ \\
\hline
\end{tabular}
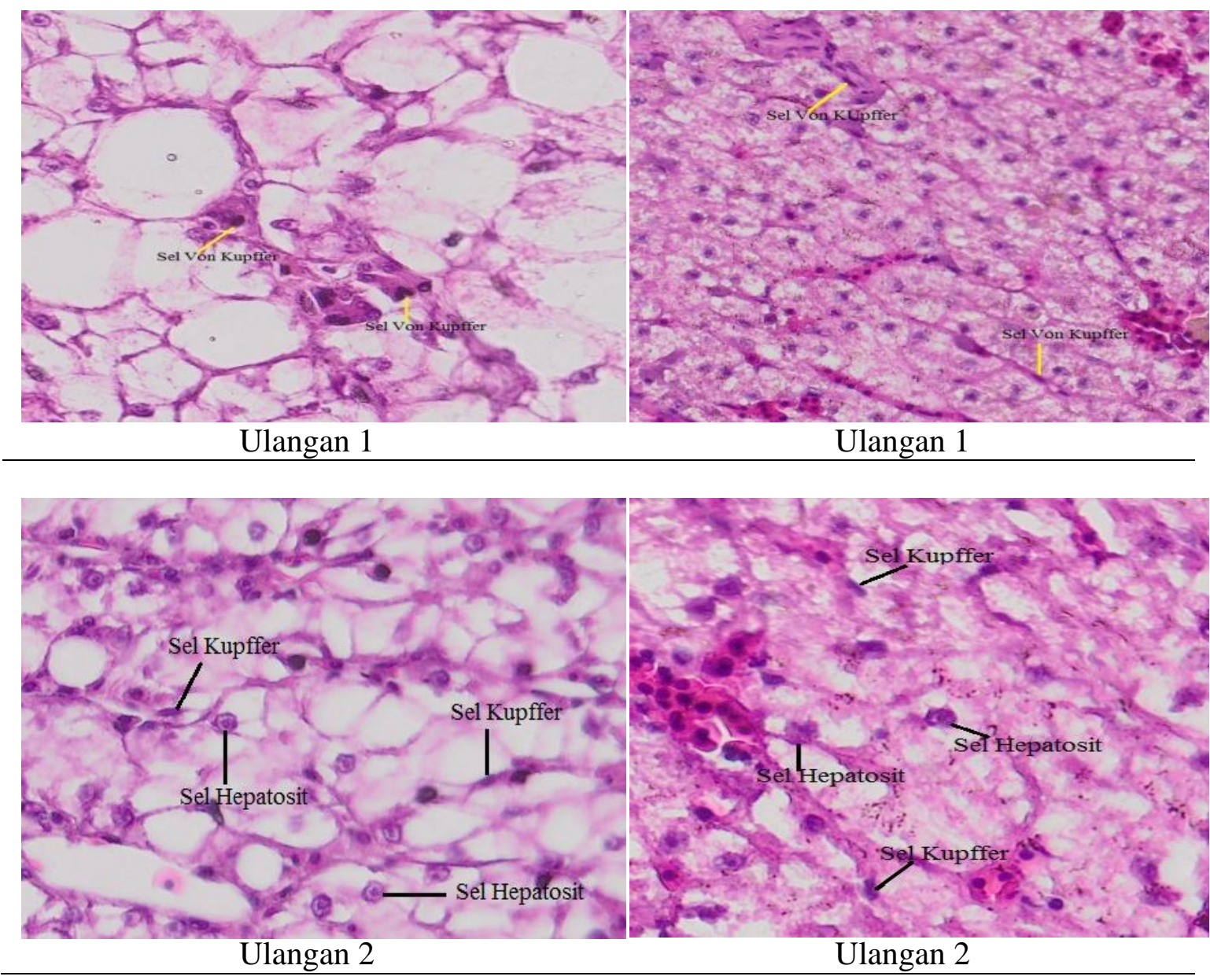


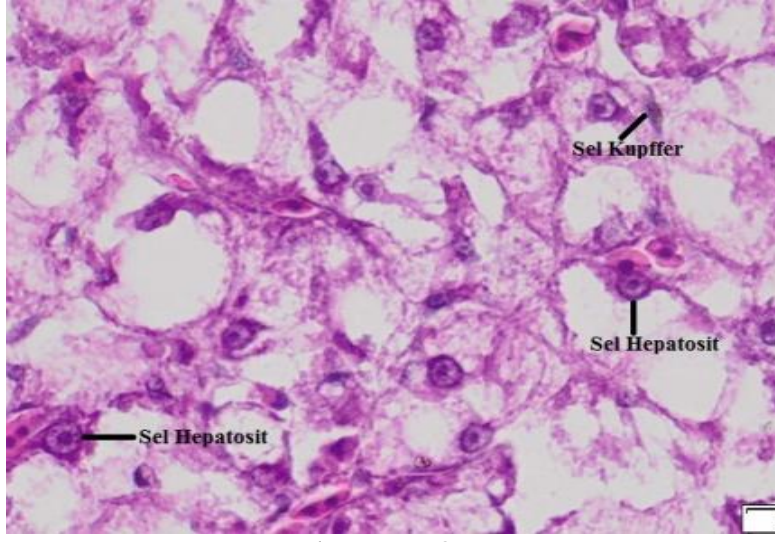

Ulangan 3

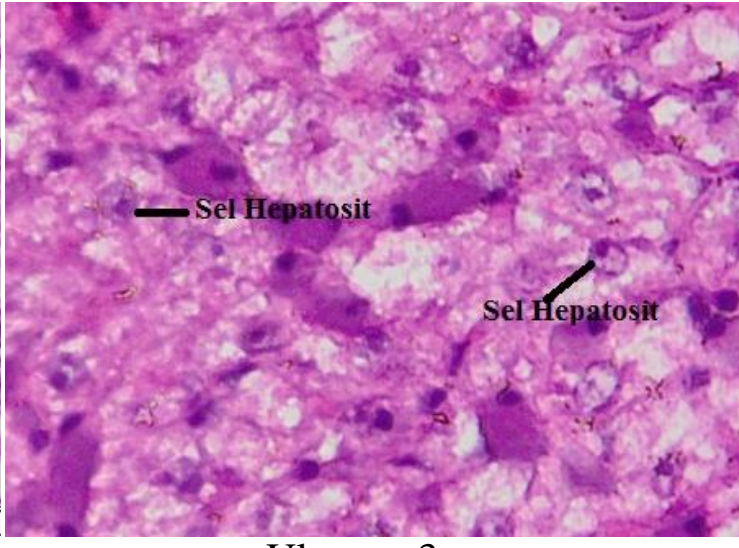

Ulangan 3

Gambar 2. Struktur hati ikan lele Afrika normal pada ulangangan 1, 2 dan 3 menunjukkan sel hepatosit berbentuk polyhedral, dengan membran sel yang jelas dan padat. Sedangkan sel kupffer tampak berbentuk lonjong atau oval yang sedikit memanjang. Pada ikan abnormal ulangan 1,2 dan 3 menunjukkan sel hepatosit yang mengalami pergeseran pada inti sel dan menyusut dan terlihat memudar saat diwarnai. Sedangkan pada sel kupffer tampak seperti garis kecil.

Struktur utama hati adalah sel hati atau hepatosit. Hepatosit (sel parenkim hati) bertanggung jawab terhadap peran sentral hati dalam metabolisme. Hepatosit normal mempunyai ciri-ciri sel tersusun secara raider, ebntuk sel bulat, oval dan terdapat lempeng-lempeng hepatosit. Sel terlihat memiliki satu nucleus, anmun ada juga yang memiliki lebih dari satu nucleus (binukleat) yang terdapat di tengah sel. Menurut (Price dan Wilson, 2005) bagian sel hepatosit yang telah mati terdapat inti yang menyusut, batas tidak teratur dan berwarna gelap dengan zat warna yang biasa digunakan oleh para ahli patologi anatomi. Proses ini dinamakan piknosis dan intinya disebut piknotik. Karioreksis ditandai dengan inti hancur dengan sel kehilangan kemampuan untuk diwarnai (pucat) atau tampak samar-samar berongga dan menghilang.

Sel Kupffer merupakan sistem monosit makrofag dan fungsi utamanya adalah menelan bakteri dan benda asing lain dalam darah. Sehingga hati merupakan salah satu organ utama sebagai pertahanan terhadap invasi bakteri dan agen toksik.

\section{Jaringan Organ Jantung Ikan Lele Afrika Clarias gariepinus}

Perbedaan struktur jaringan jantung ikan lele Afrika bersirip lengkap dengan ikan lele Afrika tanpa sirip pectoral dapat dilihat pada Gambar 3. 

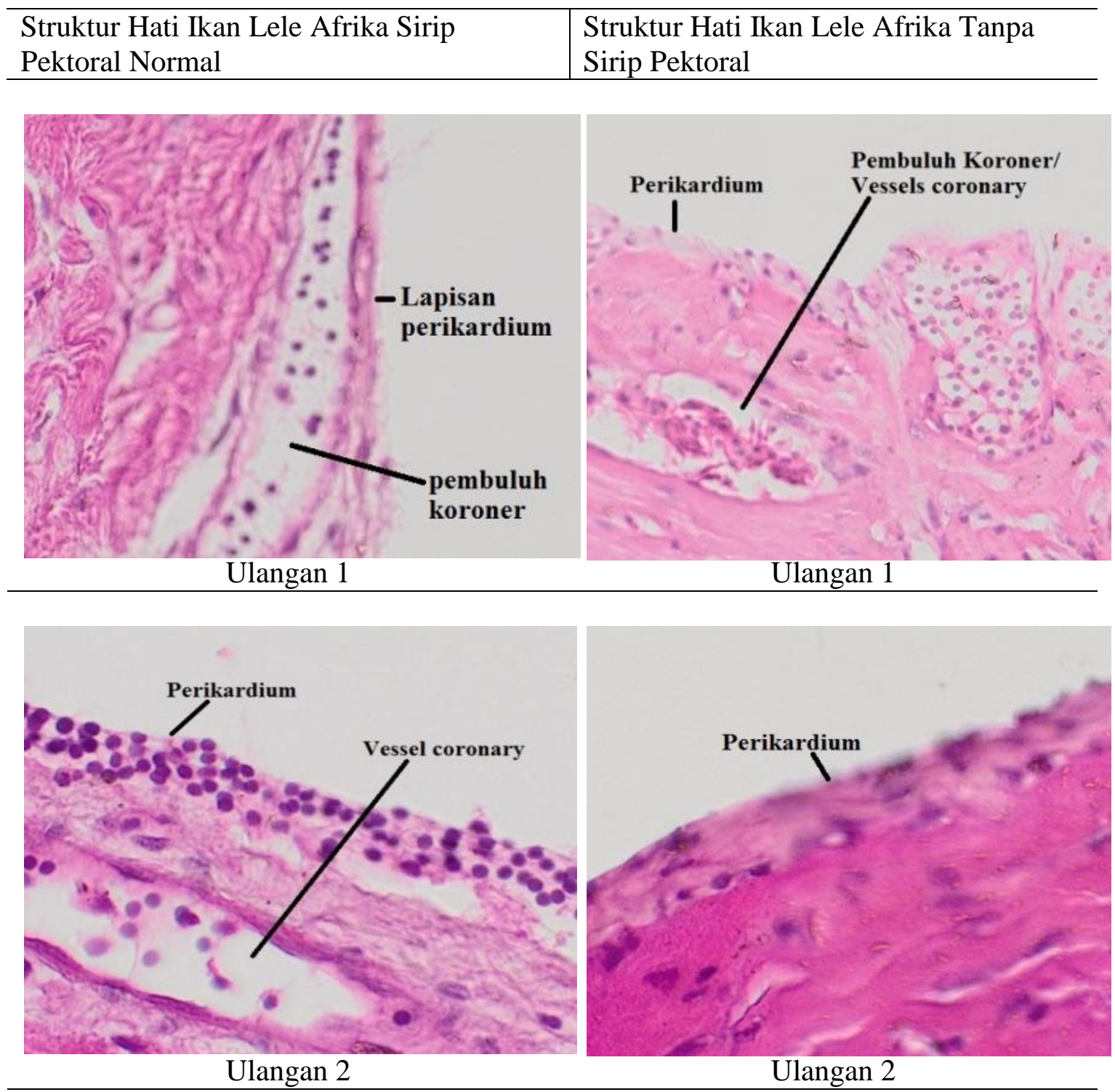

\section{Ulangan 2}

\section{Ulangan 2}

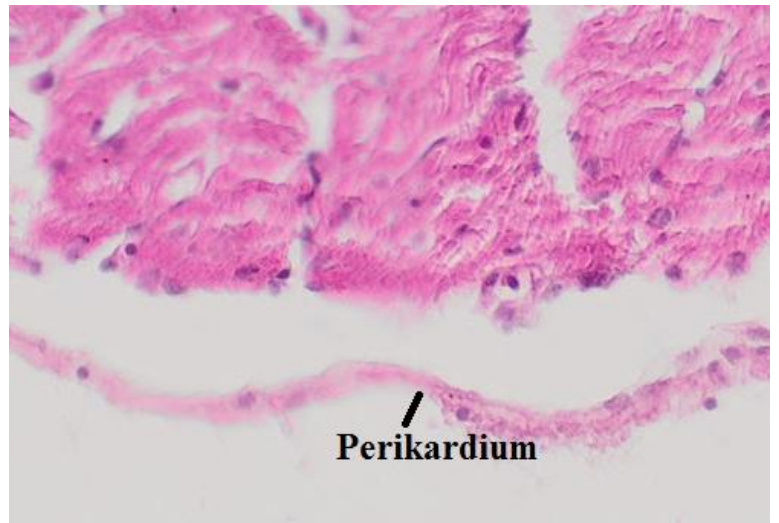

Ulangan 3

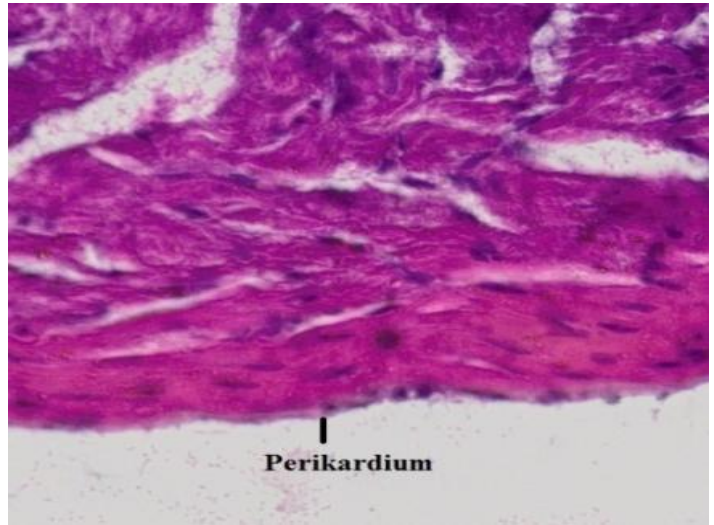

Ulangan 3

Gambar 3. Hasil organ jantung pada ikan lele afrika normal yang mempunyai organnya secara lengkap menunjukkan lapisan perikadium nampak diisi dengan banyak inti sel dan terdapat pembuluh koroner. Sedangkan pada ikan lele abnormal ulangan 1,2 dan 3 menunjukkan lapisan pericardium nampak sempit. 
Perikardium merupakan satu struktur kantung yang melapisi seluruh jantung kecuali bagian atrium kiri. Membran yang membungkus dan melindungi jantung disebut perikardium. Perikardium menahan posisi jantung agar tetap berada di dalam mediastinum, namum tetap memberikan cukup kebebasan untuk kontraksi jantung yang cepat dan kuat. Perikardium terdiri dari dua bagian, yaitu perikardium fibrosa dan perikardium serosa. Perikardium fibrosa terdiri dari jaringan ikat yang kuat, padat, dan tidak elastis. Sedangkan perikardium serosa lebih tipis dan lebih lembut dan membentuk dua lapisan mengelilingi jantung. Lapisan parietal dari perikardium serosa bergabung dengan perikardium fibrosa. Lapisan viseral dari perikardium serosa, disebut juga epikardium, melekat kuat pada permukaan jantung. Di antara perikardium parietal dan viseral terdapat cairan serosa yang diproduksi oleh sel perikardial. Cairan perikardial ini berfungsi untuk mengurangi gesekan antara lapisan - lapisan perikardium serosa saar jantung berdenyut. Rongga yang berisi cairan perikardial disebut sebagai kavitas pericardial (Scanlon, 2007).

Perikardium berfungsi untuk membungkus bagian epikardial (dalam) jantung.Selain itu, perikardium juga berfungsi untuk mempertahankan posisi jantung, menjaga fleksibilitas pergerakan jantung, memberi pelumasan, dan menahan pembesaran berlebihan yang terjadi apabila jantung terisi darah dalam jumlah yang melebihi kapasitas normalnya.Pembuluh darah koroner adalah pembuluh darah yang ada di dinding jantung dan fungsinya memasok nutrisi dan oksigen ke otot jantung.

\section{KESIMPULAN}

Berdasarkan hasil pengamatan terhadap organ ginjal ikan lele Afrika abnormal ditemukann jaringan glomerulus yang menyatu dengan kapsul bowman, Glomerulus dalam keadaan normal secara keseluruhan tertutup oleh kapsula bowman yang berbentuk seperti mangkok.Sehingga fungsi dari glomerulus sebagai penyaring darah terganggu.

Organ hati ikan lele Afrika Abnormal mengalami perubahan pada sel hepatosit yang menunjukkan dengan inti sel yang menyusut dan memudar . pada organ jantung ikan lele abnormal menujukkan lapisan pericardium yang lebih tipis dari ikan lele normal.perubahan tersebut dapat mempengaruhi kinerja dari pericardium yaitu untuk mempertahankan posisi jantung, menjaga fleksibilitas pergerakan jantung, memberi pelumasan, dan menahan pembesaran berlebihan yang terjadi apabila jantung terisi darah dalam jumlah yang melebihi kapasitas normalnya.

\section{DAFTAR PUSTAKA}

Boglione clara, Enric Gisbert, Paulo Gavaia, Paul E.Witten, Mori Moren5, St_ephanie Fontagnand Giorgos Koumoundouros. 2013. Skeletal anomalies in reared European fish larvae and juveniles. Part 2: main typologies, occurrences and causative factors. Reviews in Aquaculture (2013) 5 (Suppl. 1), S121-S167

Bruno, W.D., P.A. Noguera dan T.T. Poppe. 2010. A Colour Atlas of Salmonid Diseases. Springer Dordrecht Heidelberg, New York.

Hough C (2009) Improving the sustainability of European fish aquaculture by the control of malformations. Oral communication at the FINEFISH Final Workshop, 7 Sep 2009, held during Larvi 2009 - 5th Fish \& Shellfish Larviculture Symposium; 7-10 Sep 2009, Ghent University, Belgium.

Mc Gavin, M. D dan dan Zachary J. F. 2007. Pathologic Basic of Veterinary Disease. Mosby Incorporation, USA. 
Nurhidayat, M.A. (2000). Fluktuasi asimetri dan abnormalitas pada ikan lele dumbo (Clarias sp.) yang berasal dari tiga daerah sentra budidaya di Pulau Jawa. Tesis. Institut Pertanian Bogor. Bogor.

Price, S.A., dan Wilson, L. M., 2005, Patofisiologi: Konsep Klinis Proses-proses Penyakit, Edisi 6, Vol. 2, diterjemahkan oleh Pendit, B. U., Hartanto, H., Wulansari, p., Mahanani, D. A.,PenerbitBuku Kedokteran EGC, Jakarta.

Scanlon Valerie C, Sanders Tina, 2007 ; Buku Ajar Anatomi Dan Fisiologi (Essentials of Anatomy and Physiology) ; Edisi III, cetakan pertama ;Penerbit Buku Kedokteran EGC, Jakarta, 301 - 306.

Takashima, F. dan T. Hibiya. 1995. An Atlas Of Fish Histology Second Edition. Kodansha LTD, Tokyo. 